\title{
Ankara Vilayetinde Yolsuzluk ve Kaçakçılık Üzerine Bazı Tespitler (1908-1918)*
}

\author{
Erciment Sarıa*
}

(ORCID ID: 0000-0002-0570-8441)

\section{Makale Gönderim Tarihi}

16.12.2019

\author{
Makale Kabul Tarihi
}

30.01.2020

\section{Özet}

Tarihsel süreç içinde her devlette olduğu gibi Osmanlı Devleti'nde de bazı yolsuzluk olaylarına şahit olunmuştur. Devlet her daim yolsuzluğun önüne geçebilmek için bazı yasal düzenlemeler yapmıştır. Özellikle Tanzimat ve Meşrutiyet sürecinde yapılan düzenlemeler yolsuzluğun önlenebilmesi açısından son derece önemlidir. Ancak yapılan bu düzenlemeler yolsuzluk, rüşvet, zimmete para geçirme, irtikâp gibi kamusal ve toplumsal ahlakı zedeleyen olayları engelleyememiştir.

Kamu düzenine zarar veren bir başka olgu da kaçakçılıktır. Kaçakçılık ülke genelinde her ne kadar kıyı kesimlerde yoğun olarak görülse de iç kesimler de bundan etkilenmiştir. Anadolu ulaşım ağı içerisinde önemli bir konuma sahip olan Ankara vilayeti, kaçakçılı̆ıın geçiş güzergâhlarından biri olmuştur. Bu minvalde, çok yaygın olmamakla birlikte vilayette, kaçakçılık, özellikle de tütün kaçakçılığına ilişkin vakalara şahit olunmuştur. Bununla birlikte Ankara'nın, incelenen dönemde, kaçak tütünün pazarlanması ve tüketilmesi açısından da bir pazar konumunda olduğu söylenebilir.

Ekonomik, sosyal ve ahlaki çürümenin bir sonucu olan yolsuzluk ve kaçakçılık olgusu, Osmanlı Devleti'nin dağılma sürecinde hem merkezde hem de taşrada kamu düzeninin sağlıklı şekilde işlemesinin önündeki önemli sorunlardandır. Bu sorunlar zaman zaman Ankara vilayetinde de görülmüş ve toplumsal huzuru olumsuz yönde etkilemiştir. Yolsuzluk ve kaçakçılık vakalarının Ankara vilayetine yansımalarının ele alındığı bu çalışmanın kuramsal

\footnotetext{
* Bu makale, "II. Meşrutiyet Döneminde Ankara Vilayetinde Asayiş, Suç ve Ceza" isimli yayınlanmamış doktora tezinde yer alan, yolsuzluk ve kaçakçılık başlıklı konunun yeniden gözden geçirilmesi suretiyle üretilmiştir.

* Dr. Aksaray Üniversitesi, Atatürk İlkeleri ve İnkılap Tarihi Bölümü, ercumentsariay@gmail.com.
}

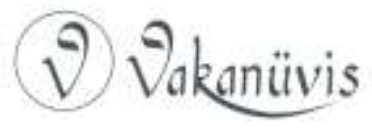


çerçevesi, yolsuzluk, rüşvet, zimmetine para geçirme, kaçakçılık (özellikle tütün kaçakçılığı) kavramları üzerine inşa edilmiştir. Çalışmanın temel amacı, incelenen dönemde Ankara vilayetinde meydana gelen yolsuzluk ve kaçakçılık vakalarını, merkezi hükümet ile yerel yönetimin bu konudaki tutumunu ve toplumun bundan nasıl etkilendiğini arşiv belgeleri ışığında ortaya koyabilmektir.

Çalışmada, Ankara, Aydın ve Trabzon vilayetlerinde yaşanan kaçakçılık faaliyetleri ana hatlarıyla karşılaştırılarak konu hakkında genel bir fikir edinilmesi amaçlanmıştır. Ancak, yolsuzluk konusunda Aydın ve Trabzon vilayetleriyle ilgili yeterli veriye ulaşılamadığından bir karşılaştırma yapılamamıştır.

Anahtar Kelimeler: Ankara vilayeti, Kamu görevlileri, Yolsuzluk, Kaçakçılık, Tütün kaçakçılığı.

\section{Some Findings on Corruption and Smuggling in Ankara Province}

\section{Abstract}

In the historical process, as in every state, some corruption incidents have been witnessed in the Ottoman Empire. The state has always made some legal arrangements to prevent corruption. In particular, the regulations made during the Tanzimat and Constitutional Monarchy periods are extremely important in terms of preventing corruption. However, these regulations could not prevent the incidents that damage public and social morality such as corruption, bribery, malversation, and perpetration.

Another fact that harms the public order is smuggling. Although smuggling is common in coastal areas throughout the country, upcountry areas also affected by this. Ankara province, which has an important position within the Anatolian transportation network, has become one of the transition routes of smuggling. In this respect, in the province, although not very common, cases of smuggling have been witnessed, especially tobacco smuggling. However, it can be said that Ankara is also a market in terms of marketing and consumption of smuggled tobacco in the examined period. The fact of corruption and smuggling, which is a result of economic, social and moral decay, is one of the important problems for maintaining a healthy public order both in the center and in the rural during the dissolution process of the Ottoman Empire. These problems have been also seen occasionally in Ankara province and affected social peace negatively. The theoretical framework of this study, which examines the reflections of corruption and smuggling cases on Ankara province, has been built on the concepts of corruption, bribery, malversation, smuggling (especially tobacco smuggling). The main purpose of this study is to

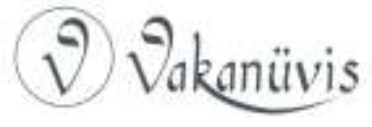


reveal the incidents of corruption and smuggling in the province of Ankara, the attitudes of the central government and the local government on this issue and how the society is affected in the light of archive documents.

This study evaluates the smuggling activities in Ankara, Aydin, and Trabzon provinces in general. However, no comparison was made for the corruptions in Aydin and Trabzon provinces as there wasn't sufficient data.

Keywords: Ankara province, Public officials, Corruption, Smuggling, Tobacco smuggling.

\section{Giriş}

İttihat ve Terakki Cemiyeti, Osmanlı Devleti'nin son yıllarına damgasını vurmuş siyasal bir örgüttür. 1908-1913 yılları arasında devlet organlarını kısmen denetimi altına alan bu örgüt, 1913'ten sonra devletin bütün organlarına hâkim olmuş, 1918'e kadar da bu hâkimiyetini sürdürmüştür. Bu süreçte devleti ve toplumu hemen her alanda dönüştürmeye çalışan İttihat ve Terakki, II. Abdülhamit döneminin siyasi ve iktisadi anlayışına karşın yenilikçi bir yol izlemiştir. Özellikle iktisadi alandaki anlayış değişikliği ve uygulamalar bunun açık bir göstergesidir.

1908 sonrasında Osmanlı yönetimini nüfuzu altına alan İttihat ve Terakki Cemiyeti'nin iktisat politikasında, 1914'e kadar liberal ve tarıma öncelik veren bir anlayış ön planda olmuştur. Bununla birlikte, cemiyet içinde korumacılık ve sanayileşmeye önem verilmesi gerektiğini savunanlar da yer almıştır. Ancak, kapitülasyonlar ve uluslararası ticari sözleşmeler tek taraflı karar almayı zorlaştırdığı için, I. Dünya Savaşı başlayana kadar iktisat politikasında istenilen değişiklikler uygulanamamıştır. Savaşın başlamasıyla birlikte itttihat ve Terakki yönetimi iç ve dış gelişmelere bağlı olarak kendi iktisat politikası olan "Milli İktisat" politikasını yürütme imkânına kavuşmuştur. ${ }^{1}$

Savaş, Osmanlı düzenini sarsarken, cephelerdeki gelişmelerden çok cephe gerisinde yaşananlar ön plana çıkmıştır. Neticede şartların da zorlamasıyla savaş ekonomisinin sebep olduğu bir yapısal değişim

${ }^{1}$ Şevket Pamuk, Türkiye'nin 200 Yıllık Iktisadi Tarihi, 8. Basım, Türkiye İş Bankası Kültür Yayınları, İstanbul 2017, s.164.

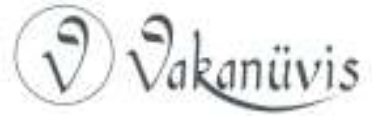


ortaya çıkmıştır. Osmanlı ekonomisinin savaş esnasında dışarıyla bağlantısının kesilmesi devleti kendi imkânlarıyla yetinmek mecburiyetinde bırakmıştır. Özellikle seferberlikle birlikte ordunun ihtiyaçları ön plana çıkmış, mal ve hizmetlerin büyük çoğunluğu bu yönde kullanılmaya başlanmıştır. ${ }^{2}$

Osmanlı'nın savaş sırasında denizden kuşatılması ve dışarıyla bağlantısının kesilmesi ithalat yollarını tıkamıştır. Bu durum Anadolu'yu, genel iaşe ve ordunun ihtiyaçlarının karşılanması açısından vazgeçilmez bir konuma getirmiştir. Ancak, Anadolu'daki nüfusun önemli bir kısmının silahaltına alınmış olması ve savaşın getirdiği belirsizlikler nedeniyle üretim düşmüş, üreticiyi pazara yönelik üretim yapmaktan alıkoymuştur. Bunun yanı sıra savaşın yol açtığı kaos, taşıma sisteminin yetersizliği, işgücü açığı ve piyasalardaki dalgalanmalar tarımsal üretimi olumsuz etkilemiştir. Bu durumda hükümet, ordunun ve sivil halkın iaşesini karşılamak için çiftçiyi ve köylüyü destekleyecek önlemler almaya çalışmıştır. ${ }^{3}$ Bu minvalde köylüye ucuz kredi verilmiş, tohum yardımı yapılmış, köylünün ürününe yüksek fiyatlar verilmiştir.

Savaş döneminde devlet, ekonominin hemen her alanını, özellikle de tarım ürünlerinin üretim, fiyat, dağıtım aşamalarını kontrol altında tutmaya büyük çaba göstermiştir. Örneğin, başkentin ve ordunun hububat ve un ihtiyacını karşılamak için Anadolu demiryolunun daha etkin bir biçimde kullanılması için, İaşe Nezareti'nin öncülüğünde vagon ticaretine başlanmıştır. Öte yandan piyasa da kıtlığı çekilen malların ithalatı ve dağıtımı için de tekeller oluşturulmuştur. ${ }^{4}$ Amaç daha öncesinde gayrimüslim tüccarların elinde bulunan ticari faaliyetlerin Türklerin eline geçmesini sağlamaktır. Böylece devlet eliyle milli burjuvazinin oluşturulması anlamında ilk adım atılmış, ordunun ihtiyaçlarının karşılanması için yapılan mal alımlarında Müslüman tüccara ayrıcalık tanınmıştır. Ancak bu ayrıcalıktan yararlanan bazı tüccarlar elindeki malı piyasaya sürmeyerek yüksek kazanç elde etmişlerdir. Bu da fiyatların artmasına neden olmuş, kentlerde ve kırsal kesimde yaşayan halkın alım gücü düşmüştür.

\footnotetext{
2 Zafer Toprak, Ittihat-Terakki ve Cihan Harbi, 2. Basım, Kaynak Yayınları, İstanbul 2016, s.33.

${ }^{3}$ Toprak, a.g.e., s.114-115.

4 Pamuk, a.g.e., 169-170.
}

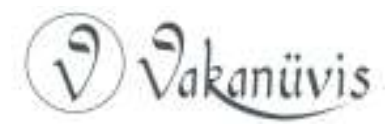


Savaş ortamında yaşanan mal darlığı ve aç gözlülük gibi etkenlere bağlı olarak yağmacılık, vurgunculuk, karaborsacılık yapıp haksız kazanç sağlayan zengin bir grup türemiştir. Merkezi hükümet bu gibi durumları önlemek için geç de olsa 1917'de “ihtikârın Men'i Hakkında Kanun-u Mavakkat"ı çıkarmıştır. Kanunda savaşın bahane edilerek mal istif edilmesi, fiyatların aşırı kâr amacıyla yükseltilmesi gibi fiiller, ihtikar yani spekülasyon olarak değerlendirilmiş, bu gibi fiillerin suç sayılacağı, faillerinin ise üç aydan üç yıla kadar hapis ve 100 liradan 5000 liraya kadar para cezasına çarptırılacakları belirtilmiştir. ${ }^{5}$ Kanunun uygulamaya konulmasıyla olumlu bazı sonuçlar elde edilmiş ise de yolsuzluk olgusu kapsamında değerlendirebileceğimiz, ihtikâr, vurgunculuk, rüşvet, zimmete para geçirme gibi vakalar hem başkentte hem de Anadolu'da var olmaya devam etmiştir.

\section{Ankara Vilayetinin Idari, Ekonomik ve Demografik Yapısı}

22 Ocak 1871'de çıkarılan “idare-i Umumiye Vilayet Nizamnâmesi” vilayet, sancak, kaza, nahiye ve köylerin yönetimini detaylı olarak ortaya koymuş, yöneticilerin görev ve yükümlülüklerini ayrı ayrı açıklamıştır. ${ }^{6}$ Söz konusu nizamnâmeye göre, Ankara vilayeti, Ankara, Yozgat, Kayseri ve Kırşehir sancaklarından meydana gelmiştir. ${ }^{7}$ II. Meşrutiyet dönemine gelindiğinde ise Ankara vilayetinde 5 sancak ve 24 kaza yer almıştır. Bu sancak ve kazalar şunlardır: Ankara sancağı ve bağlı kazalar (Ayaş, Yabanabad, Beypazarı, Sivrihisar, Bala, Mihalıççı, Nallıhan, Haymana ve Kalecik ), Çorum sancağı ve bağıı kazalar (İskilip, Sungurlu ve Osmancık ), Kayseri sancağı ve bağlı kazalar (Develi ve İncesu), Kırşehir sancağı ve bağlı kazalar (Avanos, Keskin ve Mecidiye ), Yozgat sancağı ve bağlı kazalar (Akdağmadeni ve Boğazlıyan). ${ }^{8}$ Ancak 1914'te Kayseri sancağı

\footnotetext{
${ }^{5}$ Toprak, a.g.e., s.220-221.

${ }^{6}$ Mehmet Seyitdanlıoğlu, "Yerel Yönetim Metinleri: 1871 Vilayet Nizamnamesi ve Getirdikleri" Çağdaş Yerel Yönetimler, Cilt 5, Sayı 25, 1996, s.89-99.

${ }^{7}$ Ankara Vilayet Salnamesi, 1288 (1872), 139-178. Ancak bu idari taksimat şartlara göre değişiklik göstermiş, bazı kazalar nahiyeye bazı nahiyeler de kaza statüsüne dönüştürülmüştür. Bu süreçte Yozgat'a bağlı bir kaza olan Çorum, önce sancak statüsüne yükseltilmiş, daha sonra da Ankara'ya bağlanmıştır. İskilip, Osmancık, Sungurlu kazaları da Çorum sancağına dâhil edilmiştir. Ankara Vilayet Salnamesi, 1318 (1900), 130-274.

${ }^{8}$ Devlet Salnamesi, 60. Sene, R.1328/1912, 555-564.
}

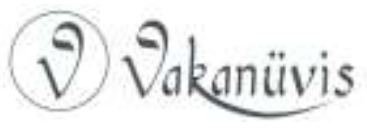


müstakil bir liva haline getirilerek vilayetten ayrılmıştır. ${ }^{9}$ Bunun yanı sıra, bazı nahiyeler kazaya dönüştürülürken, bazı kazalar da vilayetten ayrılmıştır. Örneğin 1915 yılında Mihalıççık ve Sivrihisar kazaları, müstakil liva haline getirilen Eskişehir'e bağlanmış, Çorum sancağına bağı Mecidözü nahiyesi de kaza yapılmıştır. ${ }^{10}$

Ankara vilayetinde meydana gelen idari birimlerdeki değişikliklerde, bölgenin asayiş ve emniyeti başta olmak üzere, ulaşım olanaklarının, gayrimüslimlerle ilgili tedirginliklerin, iç göçlerin, demografik hareketliliğin, ekonomik nedenlerin, etkili vergi toplayabilmenin, yönetimden kaynaklanan zorunlulukların belirleyici etkenler olduğu söylenebilir.

Vilayetin ekonomik yapısına bakıldığında, Vilayetin merkez sancağı olan Ankara, XVI. ve XVII. yüzyılda kendi intiyaçlarını karşılayabilen bir ekonomiye sahip olmanın yanı sıra, yakın ve uzak çevresiyle de ticari ilişkiler kurabilmiş bir şehirdir. Dolayısıyla Ankara, kendi imkânları çerçevesinde uluslararası ticarete dâhil olabilmiştir. ${ }^{11}$ Bu ticarette, tiftik yününden dokunan sof ve şallar önemli bir rol oynamıştır. ${ }^{12}$ Ankara ekonomisinde tarımsal faaliyetler de yer almış, ancak tarım üretiminin geleneksel metotlarla yapılması, ekilebilir alanların sadece yüzde sekizinin kullanılması harcanan emeğin karşııı̆ını verememiştir.

XIX. yüzyılda, Ankara ekonomisinde bir daralma söz konusudur. Bunun temel nedeni İngiltere'nin dokuma alanındaki egemenliğinin Ankara tekstilini tehdit etmesidir. ${ }^{13}$ Bilhassa Ingilizlerin tiftik keçisini Güney Afrika'da yetiştirmeye başlamaları, Ankara tiftiğine büyük zarar

\footnotetext{
9 Başbakanlık Osmanlı Arşivi (BOA), Dâhiliye Nezâreti İdare Evrakı (DH. iD), 212/1, 26 Cemazeyilevvel 1332/22 Nisan 1914.

10 Başkanlık Osmanlı Arşivi (BOA), Dahiliye Nezareti İdare-i Umumiye Evrakı (DH.iUM), 45/1, 16 Cemazeyilevvel 1333/1 Nisan 1915.

11 Mehmet Tunçer, Ankara (Angora Şehri Merkez Gelişimi (14-20. Yüzyıl), Kültür Bakanlığı Yayınları, Ankara 2001, 33.

12 Suraiya Faroqhi, Osmanlı'da Kent ve Kentliler, 5. Basım, Neyir Berktay (çev.), Tarih Vakfı Yurt Yayınları, İstanbul 2011, 178; Taş, a.g.e., s.60-64; Tuncer, a.g.e., s.35-36;

13 Sevgi Aktüre, 1830'dan 1930'a Ankara'da Günlük Yaşam, Tarih İçinde Ankara II, Yıldırım Yavuz (der.), ODTÜ Mimarlık Fakültesi, Ankara 2001, s.36-37.
}

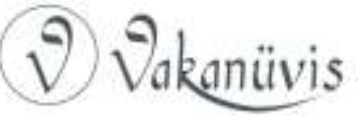


vermiştir. ${ }^{14} \mathrm{XX}$. yüzyılın başlarında ise Ankara, iktisadi açıdan oldukça zor günler geçirmiştir. Bu duruma yakından tanıklık eden Tanin Gazetesi muhabiri Ahmet Şerif, Ankara'nın büyük bir köye benzediğini, sokakların tenha ve cansız olduğunu belirterek, Ankara için oldukça karamsar bir tablo çizmiştir. Ankara'ya bağlı kazaların da merkezden pek farklı olmadığı, yol ve köprülerin bakımsız, sokakların dar, dükkânların küçük olduğu Ahmet Şerif'in gözlemlerinden anlaşılmaktadır. ${ }^{15}$

I. Dünya Savaşı sırasında Osmanlı yönetimi ağırlıklı olarak savaş ekonomisine ve devletçiliğe yönelmiştir. Savaş şartları içinde İstanbul'un iaşesi için alınan tedbirler, Ankara ticaretini de bir miktar canlandırmıştır. ${ }^{16}$ Harp sırasında şirketlerin ticari faaliyetleriyle birlikte tarım ve hayvancılık da Ankara'nın önemli ekonomik faaliyetleri içinde yer almıştır. Ancak savaşın bütün ülkede olduğu gibi Ankara'da da iktisadi yapıyı olumsuz etkilediğini söylemek mümkündür. ${ }^{17}$ Örneğin, savaş sırasında Ankara'da sürgünde bulunan Refik Halit Karay'a göre, Ankara, ağaçsız, bahçesiz, yolsuz, bakımsız ve cansız bir kenttir. ${ }^{18}$ Öte yandan 1916'da yaşanan büyük yangın Ankara'ya büyük zarar vermiş, savaşın sıkıntılarını yaşayan halkı daha zor bir duruma düşürmüştür. ${ }^{19}$

$\mathrm{Bu}$ dönemde, Ankara vilayetine bağlı diğer sancakların iktisadi yapıları Ankara sancağından çok farklı değildir. Örneğin Yozgat sancağı

\footnotetext{
14 Yusuf Güler, Ankara Vilayetinde Idari Yapının Yöredeki Sosyo-Ekonomik Yapıya Olan Etkileri (1880-1919), yayınlanmamış Doktora Tezi, 19 Mayıs Üniversitesi Sosyal Bilimler Enstitüsü Tarih Ana Bilim Dalı, Samsun 2007, s.200-206.

${ }^{15}$ Ahmet Şerif, Anadolu'da Tanin, Cilt I, Mehmet Çetin Börekçi (Haz.), Türk Tarih Kurumu Yayınları, Ankara 1999, s.69-70.

16 Vehbi Koç hatıralarında ticaretin canlanmasına ilişkin şunları söylemiştir: "Birinci Dünya Savaşı'nda Karadeniz tamamen kapalı Ruslar mayın dökmüşler, bu bölgeye ulaşım Ankara üstünden karadan yapılırdı. Samsun'a gidecek bir mal Haydarpaşa'dan trenle Ankara'ya gelir, Ankara'dan araba, at, deve sırtında giderdi. Samsun, Trabzon ve bütün Karadeniz bölgesinin ürünü tütün ve fındıklarda arabayla veya hayvan sırtında Ankara'ya gelir buradan trenle istanbul'a gönderilirdi. Isveçli Hochstrasser firmasının Türkiye'deki işlerini ikizyon adında bir Ermeni tüccar yaparmış. Babamı bu Ermeni tüccara önermişler. Hoochstrasser firmasının Samsun ve Trabzon'dan gelen fındık ve tütünlerini Ankara'da teslim alır, vagon bulur, Istanbul'a yollardık". Vehbi Koç, Hayat Hikâyem, İstanbul: Apa Ofset, 1974, s.24; Pamuk, a.g.e., s.163-174.

${ }^{17}$ Aktüre, a.g.m., s.55.

18 Refik Halit Karay, Deli, Semih Lütfi Kitabevi, İstanbul 1939, s.32-46.

${ }^{19}$ Ali Birinci, Refik Halit Karay: Ankara, İnkılap Kitabevi, İstanbul 2009, s.66-79. Yangına dair ayrıntılı bilgi için bkz. Karay, a.g.e., s.46-51.
}

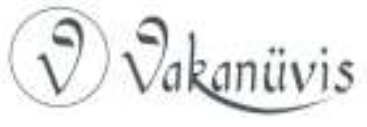


coğrafi yapısı gereği genelde göçebe hayatının yaşandığı bir bölgedir. Buna rağmen kentte küçük ölçekli sanayi ve ticaret ekonomik faaliyetler arasında yer almıştır. ${ }^{20}$ incelenen dönemde Ankara vilayetine tabi Çorum sancağı ise kısmen canlı bir ticari hayata sahiptir. Bu bağlamda şehrin kendi kendine yeterli bir ekonomiye sahip olduğu söylenebilir. Çorum ve çevresinde yapılan tarımsal faaliyetler çerçevesinde, bölgede buğday, arpa, darı, yulaf, nohut, mercimek gibi tarımsal ürünler yetiştirilmiştir. ${ }^{21}$ Vilayete bağlı diğer bir sancak olan Kırşehir'de, ticari ve ekonomik faaliyette bulunan pek çok esnaf, sanatkâr ve tüccar büyük ölçüde geleneksel Ahilik kurumuna bağlı kalmıştır. Tarım, hayvancılık ve halıcık da ekonomik faaliyetler arasında yer bulmuştur. ${ }^{22}$

Vilayetin demografik yapısına gelince, XIX. yüzyılın sonlarında, Ankara vilayetinin toplam nüfusu 763.262 Müslüman, 34.995 Rum, 67.790 Ermeni, 415 Yahudi, 6.330 Katolik ve 2.240 Protestan olmak üzere 875.000 civarındadır. ${ }^{23} 1897$ 'de ise vilayetin toplam nüfusu 1.018.727'dir. ${ }^{24} 1906^{\prime}$ da Ankara vilayetinin genel nüfus toplamı 1.157.131'dir. 1914'te Ankara vilayetinin toplam nüfusu 953.817'dir. Bu nüfusun 877.285'i Müslüman, 20.226'sı Rum, 44.507'si Ermeni, 1.026'sı Yahudi, 7.069'u Ermeni Katolik, 2.381'i Protestan'dır. ${ }^{25}$ Nüfus sayımlarına bakıldığında vilayetin demografik yapısında birtakım değişiklikler olmuştur. Savaşlar, kıtlıklar, salgın hastalıklar, asayiş sorunları ve ekonomik sıkıntılar bu değişikliklerin başlıca nedenlerindendir.

\section{Ankara Vilayetinde Yaşanan Yolsuzluklar}

Tarihin her döneminde görülen yolsuzluk, özellikle devlet teşkilatlarının oluşumuyla birlikte ortaya çıkmıştır. Yolsuzluk, devletlerin, sosyal, ekonomik, hukuki şartlarına göre artış ya da azalış

\footnotetext{
20 Taha Niyazi Karaca, Ermeni Sorununun Gelişim Sürecinde Yozgat'ta Türk Ermeni ilişkileri, Türk Tarih Kurumu Yayınları, Ankara 2005, s.31.

${ }_{21}$ M. Mahfuz Söylemez, "Vilayet Salnâmelerine Göre Osmanlı'nın Son Döneminde Çorum", Hitit Üniversitesi Ilahiyat Fakültesi Dergisi, Cilt 6, Sayı 12, 2007/2, 33-35.

22 illhan Şahin, "Kırşehir", DiA, Cilt 25, İstanbul 2002, s.483.

${ }^{23}$ Kemal H. Karpat, Osmanlı Nüfusu (1830-1914), Timaş Yayınları, İstanbul 2010, s.332.

${ }^{24}$ Tevfik Güran, Osmanlı Devleti'nin illk Istatistik Yıllığı 1897 Tarihi İstatistiksel Dizisi, Cilt 5, Başbakanlık Devlet İstatistik Enstitüsü, Ankara 1997, s.24. Bu nüfus içinde 37.000 Rum, 74.000 Ermeni bulunmaktadır.

${ }^{25}$ Karpat, a.g.e., s.336.
}

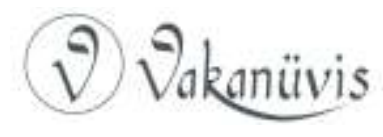


gösterebilmiştir. Yolsuzluk, genel anlamda kamu gücünün kişisel menfaatler doğrultusunda kötüye kullanılmasıdır. ${ }^{26}$ Yolsuzluğun en çok bilinen türleri ise rüşvet, zimmete para geçirme, görevi kötüye kullanma, irtikâp ve adam kayırmadır. ${ }^{27}$ Yolsuzluğun, bütün bu kavramlarla az veya çok ilişkisi olmakla birlikte, hepsini kapsayıcı mahiyette olduğunu söylemek mümkündür. Yolsuzluk, her ne kadar evrensel bir olgu olarak görülse de, devletlerin siyasi, kültürel, hukuki değerlerine göre farklılıklar gösterebilir. ${ }^{28}$

Tarihsel süreç içinde her devlette olduğu gibi Osmanlı Devleti'nde de yolsuzluk olayları görülmüştür. Devlet, süreç içinde yolsuzluğun önüne geçebilmek için bazı yasal düzenlemeler yapmıştır. Bu konuda, özellikle Tanzimat ve Meşrutiyet dönemlerinde önemli adımlar atılmıştır. Ancak, atılan bu adımların etkisi sınırlı kalmış, yolsuzluk, rüşvet, zimmete para geçirme, irtikâp gibi kamusal ve toplumsal ahlakı zedeleyen olaylar tam olarak önlenememiştir.

\section{Adliye Teşkilatında Yolsuzluklar}

II. Meşrutiyet'in ilanından sonra adliye teşkilatının ıslahına yönelik önemli adımlardan biri olan 1908-1909 tensikat düzenlemesi, ${ }^{29}$ ehliyet sahibi ve eğitimli kişilerin teşkilata alınmasını, medrese kökenli adli

${ }^{26}$ Kemal Özsemerci, Türk Kamu Yönetiminde Yolsuzluklar, Nedenleri, Zararları ve Çözüm Önerileri, Sayıştay Başkanlığı, 2003, 4-6; TEPAV, Yolsuzlukla Mücadele, 2. Basım, Matsa Basımevi, Ankara, 2006, s.23.

27 Cengiz Kırlı, Yolsuzluğun İcadı, Verita Yayınları, İstanbul, 2015, s.9.

28 Rüşvet, en genel manada, yetkili bir kişiye, bir başkası tarafından toplumun usul ve kaidelerine aykırı bir şekilde çıkar vaad edilerek ya da sağlanılarak bir işin yaptırılmasıdır. Ahmet Mumcu, Osmanlı Devleti'nde Rüşvet (Özellikle Adli Rüşvet), Ankara Üniversitesi Hukuk Fakültesi Yayınları No. 252, Ankara, 1969, s.1.

Irtikâp, haraç veya yiyicilik olarak bilinen bu kavramın rüşvetten farkı, hizmet alan tarafın ikna ya da baskıyla memura bir bedel ödemeye zorlanmasıdır. TEPAV, a.g.e., s.28.

Zimmet, memurun mal veya para gibi kamu kaynağını kanuna aykırı bir biçimde kişisel çıkarı için kullanmasıdır. Türk Hukuk Lugatı, 3. Basım, Başbakanlık Basımevi, Ankara, 1991, s.371; Özsemerci, a.g.e., s.20.

29 Tensikat: Devlet dairelerindeki memur sayısının azaltılması ve maaşlarının yeniden düzenlenmesidir. Yusuf Hikmet Bayur, Türk İnkılabı Tarihi Cilt 1, Kısım 2, Türk Tarih Kurumu Yayınları, Ankara 1991, s.90; İttihat ve Terakki Cemiyeti tarafından Abdülhamid Dönemi memur kadroları büyük ölçüde tasfiye edilmiştir. Aykut Kansu, 1909 Devrimi, Illetişim Yayınları, İstanbul 1995, s.155. Erkan Tural, “II. Meşrutiyet Dönemi'nde Adliye ve Mezahip Nezareti'nde Bürokratik Reform", AÜHFD, C 57, Sayı 2, Yıl 2008, s.229. makale aralığı: 223-252.

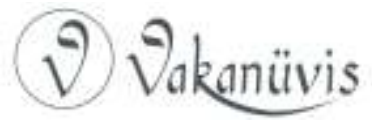


personel yerine yeni kanunlara uyum sağlayabilecek personelin getirilmesini, müfettişlerin görev ve yetkilerinin yeniden düzenlenmesini öngörmüştür. ${ }^{30}$ Bu düzenlemeye paralel ülkedeki adliye teşkilatları gözden geçirilmiş, istinaf ve bidayet mahkemeleri ile merkez teşkilatı arasındaki bağların güçlendirilmesi için müfettişlik kurumunun daha işlevsel hale getirilmesine çalışıımıştır. ${ }^{31}$ Bu çerçevede imkânlar ölçüsünde kimi yerlerde istinaf ve bidayet mahkemeleri açılmış, bu mahkemelere yapılan atamalarda personelin eğitimli olmasına dikkat edilmiştir. $^{32}$ Diğer yandan adliye teşkilatında çalışan personelin maaşlarını iyileştirmeye yönelik bazı adımlar atılmıştır. Ancak merkezde çalışan personele, taşrada çalışan personelden daha fazla maaş verilmesinin taşradaki adliyelerde rüşvet ve yolsuzluklara zemin hazırladığı, Meclis-i Mebusan'daki toplantılarda sık sık gündeme gelmiştir. ${ }^{33}$

Hukuk bürokrasisinin öncülüğünde adli sistemde yapılmak istenen değişikler, ihtiyaçları karşılamaktan uzak kalmıştır. Çünkü mali yetersizliklerden dolayı kısa sürede nitelikli personel yetiştirilememiş, taşra teşkilatları tam olarak oluşturulamamış, personelin özlük hakları iyileştirilememiş ve adalete güven tam olarak sağlanamamıştır. ${ }^{34} 4$ Haziran 1911' de adliye teşkilatına dair geniş kapsamlı bir nizamnamenin hazırlanarak uygulamaya konulması, taşra teşkilatlarının sorunlarını tam olarak çözememiştir. Bu sorunların başında ise yolsuzluk, rüşvet ve suiistimal gibi vakalar gelmektedir. ${ }^{35}$

Ele alınan dönemde ülkenin her yerinde olduğu gibi Ankara vilayetinin adli kurumlarında da rüşvet, suiistimal, yolsuzluk gibi vakalara rastlanmıştır. Örneğin, Ankara'ya vilayetine bağı Kırşehir sancağı adliyesinde bazı memurlar görevlerini suiistimal etmişlerdir. Şikâyetlerin artması üzerine, Dâhiliye Nezareti Ankara valiliğine gönderdiği yazıda, konu hakkında tahkikat yapılmasını ve neticesinin

30 MMZC, Cilt 1, İçtima 87, 25 Mayıs 1325/6 Haziran 1909; s.153-166. Tural, a.g.m., s.232; Düstur, II. Tertib, Cilt II, s.33; Tanin, Sayı 441, 11 Teşrinisani 1325/24 Kasım 1909.

31 Tural, a.g.m., s.233.

32 Tanin, Sayı 361, 21 Ağustos 1325/3 Eylül 1909.

${ }_{33}$ MMZC, Cilt 2, İçtima 100, 17 Mayıs 1326/30 Mayıs 1910, 574-593.

${ }^{34}$ MMZC, Cilt 2, İçtima 73, 30 Mart 1327/11 Nisan 1911, s.42-52.

35 Düstur, II. Tertib, Cilt III, s.467-479.

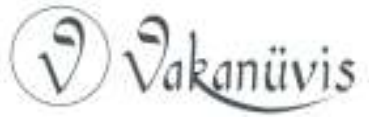


bildirilmesini istemiştir. ${ }^{36}$ Rüşvet alınmasıyla ilgili olarak Ankara valiliğinden Dâhiliye Nezâreti'ne yazılan bir yazıda, Avanos kazası halkının Adliye'de rüşvetsiz iş gördüremediği ve Kaymakamın buna göz yumduğu ifade edilmiştir. Azadamard isimli gazetede bu hususla ilgili çıkan bir yazıda ise Avanos kazası mahkemesinde görevli müddeiumumi muavini $\mathrm{HaCl}$ ve müstantik Mustafa Bey'in kanun dairesinde hareket etmedikleri ve mahkeme işlemlerinde usulsüzlük yaptıkları, bunun yanı sıra ceza reisi Salih Bey'in görev sırasında diğer görevlilere hakaret ettiği ifade edilmiştir. 14 Mart'ta Dâhiliye Nezâreti'nden Adliye Nezâretine gönderilen yazıda Avanos Nizamiye Mahkemesi'nde işlerin düzenli yürümediği ve rüşvetsiz iş yapılmadığına yer verilmiştir. ${ }^{37} \mathrm{Bu}$ tür vakalara yalnızca Adliye mahkemelerinde değil, Şer'iye Mahkemelerinde de tesadüf olunmuştur. Örneğin, Ankara'nın $\mathrm{Hacl}$ Musa Mahallesi Camisi imamı Bahri ve aynı mahalleden Abdülkerim Efendi ile Esderzâde Mehmed Efendi, vakıf malına bakma davasında mahkeme başkâtibi Hacı Mehmed Efendi'nin kusurlu olduğunu iddia etmişlerdir. Yapılan inceleme sonucunda Hacı Mehmed Efendi, Ceza Kanunu'nun yüz ikinci maddesi gereğince bir aylık maaş kesimiyle cezalandırılmıştır. ${ }^{38}$ Şüphesiz ki bu misallere bakarak adli teşkilatta suiistimal ve rüşvet olaylarının çok yaygın olduğunu söyleyerek bir genelleme yapmak doğru değildir. Bütün zorluklara rağmen görevlerini fedakârlıkla sürdüren mahkeme görevlilerini de unutmamak gerekir.

\section{Zimmete Para Geçirme, Rüşvet ve Usulsüz ihale Vakaları}

1908'den itibaren Osmanlı bürokrasisinde büyük bir değişim yaşanmıştır. Büyük küçük bütün memurları yakından ilgilendiren değişim sonucunda II. Abdülhamit döneminin kadroları büyük ölçüde tasfiye edilmiştir. Tasfiye sürecinde 1908-1909 tensikat düzenlemesinin önemli bir yeri vardır. ${ }^{39}$ Düzenlemeyle tasfiye edilen memur kadrolarının yerine peyderpey yenileri atanmıştır. Bununla birlikte tasfiyeler özellikle taşra bürokrasisinde bazı sıkıntılara yol açmıştır.

\footnotetext{
${ }^{36}$ BOA, DH. MUi. 23/70, 11 Şevval 1327/26 Ekim 1909.

37 Başbakanlık Osmanlık Arşivi (BOA), Dâhiliye Nezâreti Mütenevvia Kısmı Evrakı (DH. MTV.), 19/12, 26 Rebiülevvel 1329/27 Mart 1911.

38 BOA, DH. MTV. 21/77, 9 Recep 1329/6 Temmuz 1911.

39 Tensikat düzenlemesi hakkında ayrıntılı bilgi için bkz. Carter V. Findley, Osmanlı İmparatorluğu'nda Reform: Babıâli, 1789-1922, Tarih Vakfı Yurt Yayınları, İstanbul 2014, s.343-348.
}

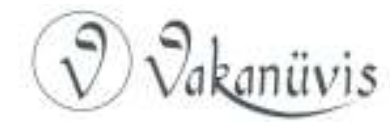


Boşalan kadrolar kısa sürede doldurulamadığı gibi, memur maaşları da düzenli olarak ödenememiştir. Öte yandan tasfiye edilen memurların bir kısmı da mağdur edildiklerine dair şikâyetlerde bulunmuşlardır. ${ }^{40} \mathrm{Bu}$ arada Trablusgarp, Balkan ve I. Dünya Savaşları memurların sıkıntılarını daha da artırmıştır. Osmanlı hükümeti sıkıntıların giderilmesi için memurların emeklilik, maaş ve sosyal yardım gibi haklarını yeniden düzenlemiştir. Düzenlemenin ardından memurlara bir miktar yiyecek yardımı yapılmıştır. Yardımlardan daha çok başkentteki memurlar yararlanırken, taşradaki memurları ise bundan çok az istifade etmiştir. ${ }^{41}$

Büyük savaşla birlikte temel tüketim ürünlerinin fiyatlarının sürekli yükselmesi, buna karşın maaşların sabit kalması zaten düşük ücretle çalışan memurların geçinmelerini daha da zorlaştırmıştır. ${ }^{42}$ Bu durumda memurların bir kısmı ticaret yaparak, diğer bir kısmı da hukuk dışı yollara başvurarak geçimini temin etmeye çalışmıştır. Yolsuzluk, rüşvet ve zimmete para geçirme gibi yasa dışı fiillerin hem başkentte hem de taşrada yaşanması bunun bir sonucudur. Bu türden yasa dışı faaliyetlerde bulunanların büyük çoğunluğunun kamu görevlisi oldukları arşiv belgelerinden anlaşılmaktadır. Bu gibi faaliyetlerle ilgili olarak farklı bölgelere dair birçok kayıt bulunmakla birlikte konumuzun sınırlarını aşmamak adına aşağıda Ankara vilayetinde yaşanan ve kamu görevlilerinin karıştıkları vakalardan bazı örnekler üzerinde durulmuştur. 3 Ağustos 1911 tarihinde Maliye Nezâreti'nden Dâhiliye Nezâreti'ne yazılan bir yazıdan sandık emininin vazifesi esnasında zimmetine para geçirdiği ve Keskin kazası mal müdürü Zeki Bey'in de buna göz yumduğu iddia edilmiştir. Zeki Bey hakkında soruşturma açılmış ise de dosyası şûrâ-yı Devlet'te incelenerek hakkında beraat kararı verilmiştir. ${ }^{43}$ Zimmete para geçirme konusundaki başka bir soruşturmada, Ankara'nın Zir nahiyesi eski tahsildarı Matosyan Bagos Efendi, soruşturma neticesinde suçlu bulunarak Ceza Kanunu'nun doksanıncı maddesi gereğince üç ay müddetle hapis cezasına

40 Tanin muhabiri Ahmet Şerif, taşrada görev yapan memurların tensikat düzenlemesinden büyük endişe duyduklarına, tensikatın zaman zaman yanlış uygulandığına, namuslu ve yetenekli bazı memurların mağdur edildiğine şahit olmuştur. Ahmet Şerif, a.g.e., s.78.

${ }^{41}$ Findley, a.g.e., s.379-385.

42 Pamuk, a.g.e., s.172.

${ }^{43}$ BOA, DH. MTV. 21/85, 12 Şaban 1329/7 Ağustos 1911.

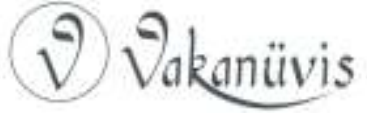


çarptırılmış, ayrıca zimmetine geçirdiği paranın kefillerinden alınmasına karar verilmiştir. Ankara Vilayet Meclisi'nin aldığı bu karar, Şurâ-yı Devlet İstinaf Mahkemesi tarafından bozularak, hapis cezası kaldırılmış, Bagos Efendi'nin itirafı gereği bin yedi yüz seksen kuruşun mahkeme masraflarıyla birlikte hazineye ödemesine karar verilmiştir. ${ }^{44}$

Ankara vilayeti Kırşehir sancağı Keskin kazası Sandık Emini Yasef Efendi'nin, zimmetine para geçirdiği iddiasıyla hakkında tahkikat yapılmış, Vilayet Meclisi'nce mahkûmiyetine karar verilmiştir. Yasef Efendi karara itiraz ederek temyize götürmüştür. Ancak Şûrâ-yı Devlet Vilayet Meclisi'nin kararını onaylamıştır. ${ }^{45}$ Zimmetine para geçirme iddiasıyla yargılananların genellikle tahsildarlar ve sandık eminleri oldukları belgelerden anlaşımaktadır. ${ }^{46}$ Ankara vilayetinde tahsildarların, sandık eminlerinin yanı sıra diğer kamu görevlilerinin de yolsuzluklarına şahit olunmuştur. Yabanabad kazası reji memurlarından Zekeriya Sırrı Efendi reji idaresi hâsılatından zimmetine para geçirmiş ve suçlu bulunmuştur. Şûrâ-yı Devlet, bu kişinin temyiz başvurusunu reddetmiştir. ${ }^{47}$ Kırşehir posta memurlarından Mehmet Nuri Efendi, havale ve emanette biriken paradan zimmetine para geçirmekle suçlanmıştır. Ankara Vilayet Meclisi konuyu görüşerek Mehmet Nuri Efendi'nin memuriyetten uzaklaştırılmasına, üç ay süreyle hapsine ve zimmetine geçirdiği iki bin kuruşu iade etmesine karar vermiştir. Mehmet Nuri Efendi karara itiraz ederek temyize başvurmuştur. Şurâ-yı Devlet Temyiz İdaresi, başvuruyu inceleyerek Ankara Vilayet Meclisi'nin kararını onaylamıştır. Ancak görevden uzaklaştırma cezasının süresi belirtilmediğinden kararın bu kısmını bozmuştur. ${ }^{48}$ Yukarıdaki örneklerden de anlaşıldığı gibi, genellikle parayla ilişkili olarak görev yapan memurların rüşvet ve zimmete para geçirme gibi suçlara karıştıkları görülmektedir. Bunun temel sebebi para kaynaklarına ve kullanımına yakın olan bu kişilerin gösterdikleri zafiyettir.

\footnotetext{
44 BOA, DH. MTV. 21/12, 3 Zilkade 1329/26 Ekim 1911.

45 BOA, DH. MTV. 21/70, 24 Safer 1330/13 Şubat 1912.

46 BOA, DH. MTV. 36/13, 23 Rebiülahir 1330/12 Nisan 1912; BOA, DH. MTV. 36/42, 17 Cemazeyilahir 1330/12 Nisan 1912; BOA, DH. MTV. 49/15, 11 Zilkade 1330/13 Ekim 1912; BOA, DH. MTV. 20/18, 2 Ramazan 1331/5 Ağustos 1913.

47 BOA, DH. MTV. 21/73, 26 Safer 1330/15 Şubat 1912.

48 BOA, DH. MTV. 49/30, 1 Zilhicce 1330/23 Ekim 1912.
}

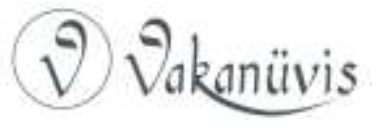


II. Meşrutiyet dönemine değin aşarın tahsil edilmesinde emanet usulü, ihale usulü ve tahmis usulü gibi üç temel metot uygulanmıştır. Meşrutiyet'in ilanından sonra ise başlangıçta tahmis usulü benimsenmiş ise de çeşitli nedenlerle bu usul tam olarak uygulanamamıştır. ${ }^{49}$ Dolayısıyla aşarın tahsilinde ağırlıklı olarak ihale usulünün uygulanmasına devam edilmiş, usulün merkezinde ise yine mültezimler yer almıştır. Aşarın toplanması ve teslimi sürecinde mültezimlerle resmi görevliler arasında yasal çerçevede sürdürülmesi gereken ilişkiler zaman zaman suiistimal edilmiştir. Aşar ihaleleri kanun ve nizamnamelere uygun olarak yapılmamış, kişisel çıkarlar ön plana çıkmış, devlet ve halk bundan zarar görmüştür. Bu tür suiistimallere özellikle kırsal alanda yapılan aşar ihalelerinde sıklıkla tesadüf edilmiştir. Örneğin Ankara sancağına tabi Keskin kazası ve köylerinde aşar ihalesinde yolsuzluklar yapıldığı yapılan tahkikat neticesinde anlaşılmış ve ihale iptal edilmiştir. ${ }^{50}$ Aşarın tahsiliyle ilgili bir başka vakada ise, Ankara Duyun-ı Umumiye İdaresi Aşar Kalemi kayıt memurlarından Mustafa Efendi, aşar mültezimlerinden Kasap Tevfik Efendi'nin Duyun-ı Umumiye sandığına teslim ettiği paradan beş bin kuruşu zimmetine geçirmiştir. Yapılan soruşturma neticesinde Mustafa Efendi ve kefilinin bu parayı iade etmesi istenmiştir. ${ }^{51}$

Incelenen dönemde Ankara vilayetine tabi bazı sancakların mutasarrıfları ve belediye başkanları da yasadışı yollara başvurarak usulsüzlüklere ve yolsuzluklara bulaşmışlardır. Örneğin Yozgat Mutasarrıfı Ömer Mümtaz Efendi'nin hırsızı̆̆ı kanıtlanmış belediye azası Manyusi Efendi'yi koruyup kolladığı yine bir Ermeni olan Çalkıyan Efendi'nin şikâyet dilekçesinden anlaşılmıştır. ${ }^{52}$ Mihalıççık kazası kaymakam vekili Haykazon Efendi ise rüşvet aldığı iddiası Şûrâ-yı Devlet'in ilgili encümeni tarafından tahkik edilmiş, davasının görülmesi için dosyası Adliye Nezâreti'ne gönderilmiştir. ${ }^{53}$ Diğer bir usulsüzlük

\footnotetext{
49 Ergül Ballı, "ittihat ve Terakki'nin Tarım ve Toprak Politikası: Aydın Vilayeti Örneği”, Ittihatçılar ve İttihatçıı Sempozyumu Bildiriler Cilt III, 25 Kasım 2014, Türk Tarih Kurumu Yayınları, Ankara 2015, s.133.

50 BOA, DH. ID. 181/1, 5 Cemazeyilevvel 1331/12 Nisan 1913.

${ }^{51}$ BOA, DH. MTV. 62/7, 22 Şaban 1331/27 Temmuz 1913.

52 BOA, DH. MTV. 18/90, 16 Zilkade 1331/17 Ekim 1913.

${ }^{53}$ Başbakanlık Osmanlı Arşivi (BOA), Bab-ı Ali Evrak Odası (BEO), 4200/314996, 25 Şaban 1331/30 Temmuz 1913.
}

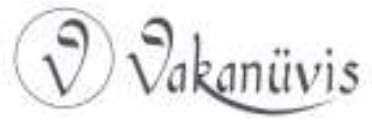


olayını müfettiş Ali Seyit Bey ortaya çıkarmıştır. Ankara mülkiye müfettişi olan Ali Seyit Bey, Kırşehir belediyesini teftiş etmiş, belediyedeki usulsüzlükleri tespit ederek, hazırladığı raporu Dâhiliye Nezâreti'ne göndermiştir. Raporda, gelir ve giderlerin deftere kaydedilmediği, makbuzların adi kâğıtlara yazıldığı, sandık eminine ait kefalet senedi bulunmadığı, hesaplarda açık bulunduğu belirtilerek, belediye reisi ve kâtibinin soruşturulmaları gerektiği ifade edilmiştir. Buna mukabil Ankara valisi, Dâhiliye Nezâreti'ne gönderdiği yazıda, konunun araştırılacağını ve neticesinin en kısa sürede bildirileceğini belirtmiştir. ${ }^{54}$ Çorum belediyesini teftiş eden vilayet mülkiye müfettişi Arif Bey de hazırladığı raporda benzer yolsuzluklara dikkat çekmiştir. ${ }^{55}$

\section{Vurgunculuk}

I. Dünya Savaşı'nın çıkması, hem cephede hem de cephe gerisinde önemli ölçüde bir iaşe sorununa yol açmıştır. Savaş esnasında, Çanakkale Boğazı'nın kapatılarak Akdeniz'le bağlantının kesilmesi, Rusya'nın savaşa girmesi ve Romanya'dan ithal edilen un fiyatlarının artması, önce İstanbul'da, daha sonra da bütün ülkede un sıkıntısının yaşanmasına sebep olmuştur. Diğer yandan seferberlikten dolayı Anadolu demiryolu hatlarında asker sevkiyatı yapıldığı için bir süre bu hatlardan da İstanbul'a buğday ve un sevk edilememiştir. Dolayısıyla durum daha da güçleşmiştir. Sorunu gidermek için İttihat ve Terakki Cemiyeti'nin İstanbul murahhası Kemal Bey'in başkanlığında “Heyet-i Mahsusa-i Ticari" adıyla bir kurul oluşturularak iaşe işleri bu kurul tarafından üstlenilmiştir. Böylece Anadolu'daki tahıl merkezleriyle hızlı ve etkili bir bağlantı kurulmuştur. Illk olarak İstanbul'a günde 20 vagon üzerinden 3600 vagon buğday sevki için Konya tüccarıyla anlaşılmış, ardından buna benzer bir anlaşma Ankara tüccarıyla da yapılmıştır. ${ }^{56}$ Savaş boyunca buğdayın yanı sıra birçok ürün vagonlarla Ankara ve Konya vilayetinden İstanbul'a taşınmıştır. Ancak, vagonların İttihat ve Terakki'ye yakın tüccarlara tahsis edilmesi ve tüccarların vagon ticareti esnasında fiyatları manipüle etmeleri bazı suiistimallere yol açmış, ${ }^{57}$ bazı

\footnotetext{
${ }^{54}$ BOA, DH. ID. 218/53, 15 Zilhicce 1332/4 Kasım 1914.

55 BOA, DH. ID. 218/30, 1 Cemazeyilevvel 1333/17 Mart 1915.

56 Toprak, a.g.e., s.171-175.

57 Bu konuda Ali Haydar Mithat şunları söylüyordu: "Şeker, gaz, kahve, yağ, pirinç, buğday gibi ihtiyacı zaruriye eşyası, ihtikâr yüzünden, görülmemiş fiyatlara fırlamış
}

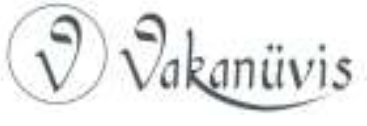


bölgelerde muhtekirler (vurguncular) ve stokçular türemiştir. ${ }^{58}$ Örneğin, dönemin Ankara valisine Enver Paşa tarafından vagon ticareti için bir vagon tahsis edilmiştir. Ancak vali bey bu ticareti kendi çıkarlarına alet ederek haksız kazanç sağlamıştır. Konuyla ilgili olarak Ali Haydar Mithat Bey'in hatıralarında yer alan şu ifadeler oldukça dikkat çekicidir: "Bir gün, Sipahi Kulübünde, Enver Paşa'ya rast geldiğim sırada kendisine dedim ki: $\mathrm{Bu}$ memleket, bir hayat memat mücadelesine atılmış bulunuyor. Halkın zararına, şunun bunun vagon ticareti yapmasına nasıl müsamaha gösteriyorsunuz? Enver Paşa, açık ve samimi bir ifade ile bana şu cevabı verdi: Ben, istisnai olarak, yalnız bir tek adam hakkında böyle bir müsaade verdim. O zaman, işin böyle olacağını kestirememiştim. Ankara Valisi ahbabımdır. Çok borçlanmış olduğunu ileri sürerek, 1.000 lira kadar bir para kazanmak üzere, benden bir vagon istedi. Ben de, Levazım Reisi İsmail Hakkı Paşa'ya, bu zata bir vagon vermesini söyledim. Ne bilirdim ki, vagonu başka birine satıp 9.000 lira alacak ve bu istisnai müsaade, birçok kirli suiistimallere kapı açacaktır. Fakat artık şimdi kat'i kararlar almış bulunuyorum. Bundan sonra kimseye vagon verilmeyecektir". ${ }^{59}$

Hükümet seferberlik esnasında ordunun ihtiyacı olan hayvan, araç ve mal temini konusunda bazı sınırlamalar getirmiştir. Ancak hayvanların sayımı ve teslimi esnasında bazı yolsuzlukların yaşandığı yapılan teftişlerden anlaşılmıştır. Ankara mülkiye müfettişleri tarafından yapılan teftişlerde, Ankara merkez kaza ile Haymana, Beypazarı ve Mucur kazalarında bu türden yolsuzlukların yaşandığı tespit edilmiştir. ${ }^{60}$

Savaş sırasında yaşanan fiyat spekülasyonlarından bunalan halk bu durumdan şikâyetçi olmuştur. Bunun üzerine Dâhiliye Nezâreti, Ankara

\footnotetext{
bulunuyordu. Mahdut nakliye imkânlarının halkın lehine kullanılması lâzım gelirken, şunun bunun zenginleşmesi için bir vasıta haline ifrağ edilmişti. Birçokları büyük bir hırsla vagon ve koli ticaretine, zaruri ihtiyaç eşyasına ait ihtikârlara atılmış bulunuyordu. Halkın açlığı ve sağlığı pahasına kazanılan paraların büyük bir kısmı rezilane şekilde sarf ediliyor, rastgele israf olunuyordu". Ali Haydar Mithat, Hatıralarım 1872-1946, İstanbul: Akçit Yayın, 1946, 313.

58 Kanuna göre, stokçuluk yapan esnaf veya tüccara beş liradan yüz liraya kadar para cezası, bir haftadan üç aya kadar hapis cezası ya da her ikisinin birlikte verilmesi öngörülmüştür. Takvim-i Vekayi, Sayı 2919, 19 Haziran 1333/19 Haziran 1917.

${ }^{59}$ Ali Haydar Mithat, a.g.e., s.313.

${ }^{60}$ BOA, DH. I. UM. 83/1, 18 Rebiülevvel 1333/3 Şubat 1915.
}

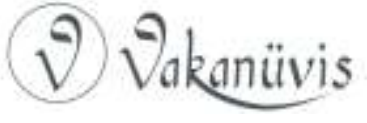


vilayetine çektiği telgrafta fiyatların usulüne uygun olarak belirlenmesini ve halkın mağdur edilmemesini istemiştir. ${ }^{61}$ Yine bu çerçevede bazı ordu mensuplarının cebri mubayaa ile elde ettikleri malları kendi namlarına sattıkları tespit edilmiş ve vilayetlerin bu gibi durumlarda dikkatli olmaları gerektiği bildirilmiştir. ${ }^{62}$

\section{Ankara Vilayetinde Kaçakçılık}

Kaçakçılık, resmi gümrük uygulamalarından kaçarak devlete maddi zarar vermenin yanı sıra, toplumsal ve siyasal yapıyı olumsuz etkileyen bir eylemdir. Kaçakçılık, kanunlarla yasaklanmış bir faaliyettir ve suç olarak değerlendirilmiştir. Bu bağlamda kaçakçılığın, fiilen katl, yaralama, adam kaçırma, vb. suçlarla bağlantılı olduğu, toplumda emniyet ve asayişin zedelenmesine sebebiyet verdiğini söylemek mümkündür. Kaçakçıllar, her ne kadar toplumsal hayatta kötü bir imaja sahip olsalar da, bazı dönemlerde devletlerin kimi uygulamalarından dolayı toplumda kendilerine destek olacak birilerini kolaylıkla bulabilmişlerdir. Örneğin, Osmanlı Devleti'nde Duyun-ı Umumiye ve ardından kurulan Reji İdaresi'nin uygulamalarına tepki gösterenler kaçakçıları koruyup kollamışlardır.

Kaçakçılığın ekonomik ve toplumsal yapıya verdiği zararın yanı sıra, siyasi ve askeri alana da sirayet ettiği söylenebilir. ${ }^{63}$ Osmanlı Devleti'nde meydana gelen Ermeni, Rum, Sırp, Bulgar ve diğer ayrılıkçı faaliyetlerde bazı büyük devletlerin bu toplumlara zaman zaman kaçak yollardan silah temin ettikleri bir gerçektir. ${ }^{64} \mathrm{Bu}$ gibi durumlarda Osmanlı Devleti ile bu devletler siyasi ve askeri bakımdan karşı karşıya gelmişlerdir.

Bir başka açıdan kaçakçııı; bir emtianın yasalara veya kanunlara aykırı olarak gizli bir şekilde bir ülkeye, coğrafyaya ya da bir devletin sınırları içerisine sokmak veyahut çıkarmak olarak da tanımlanabilir. Bu

\footnotetext{
61 Başbakanlık Osmanlı Arşivi (BOA), Dâhiliye Nezâreti Şifre Kalemi Evrakı (DH. ŞFR.), 56/297, 26 Zilkade 1333/7 Ekim 1915.

62 BOA, DH. ŞFR. 79/159, 5 Zilhicce 1335/23 Eylül 1917.

63 Olcay Pullukçuoğlu Yapucu, Aydın Sancağı 1845-1914 (Sosyal, Ekonomik, Idari, Kültürel Durum), Yayımlanmamış Doktora Tezi, Ege Üniversitesi Sosyal Bilimler Enstitüsü, Tarih Anabilim Dalı, İzmir 2006, s.178-179.

${ }^{64}$ Kubilay Hamzaoğlu, Trabzon Vilayeti'nde Kaçakçılık (1855-1908), Yüksek Lisans Tezi, Ondokuz Mayıs Üniversitesi Sosyal Bilimler Enstitüsü Tarih Anabilim Dalı, Samsun 2019, s.62-63.
}

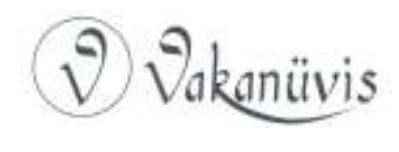


işi yapan şahıs ve zümrelere ise kaçakçı denilmiştir. Kaçakçılığın, ekonomik ve ticari değere sahip bir emtianın vergilendirilmesiyle başladığını söylemek mümkündür. Keza vergi kaçırarak kâr amacı gütmek kaçakçıların temel amaçlarından biridir. ${ }^{65}$ Bununla birlikte bir ürün üzerindeki çeşitli yasaklamaların kaçak ürün ve kaçakçıı̆ıın oluşmasına katkı sağladığı söylenebilir. Toplumsal hayatta bir suç unsuru olan kaçakçılık, katl, yaralama, adam kaçırma, tecavüz vb. eylemlerle emniyet ve güven duygusunun zarar görmesine neden olmuştur.

Öte yandan kamu düzenine ve güvenliğine zarar veren kaçakçılık, ülke genelinde her ne kadar kıyı kesimlerinde yoğun olarak görülse de iç kesimlerde bundan etkilenmiştir. Ankara vilayeti Anadolu ulaşım ağı içerisinde önemli bir konuma sahip olduğu için kaçakçıların geçiş güzergâhı olarak kullandıkları alanlar içinde görülebilir. Her ne kadar kaçakçılığın, (köle, tütün, silah, tuz, maden vb.) farklı türleri bulunsa da Ankara vilayetinde yapılan kaçakçılığın büyük ölçekte olmasa da tütün mamulü üzerinde yoğunlaştığı söylenebilir. Ankara ve çevresi daha çok kaçak tütünün pazarlanması ve tüketilmesi açısından bir pazar yeri konumunda olmuştur. Yine de çok yaygın olmamakla birlikte Ankara vilayetinde de tütün kaçakçılığına rastlanmıştır.

\section{Tütün Kaçakçıllığı}

Tütün, anavatanı olan Amerika'dan, coğrafi keşifler sonucunda Akdeniz yoluyla Anadolu'ya girmiş ve kısa sürede ticari bir meta olarak kullanılmaya başlanmıştır. ${ }^{66}$ Zaman içinde tütün, Anadolu'da, iç piyasada tüketilmesinin yanı sıra bir ihraç ürünü olarak da pazarlanmaya başlanmıştır. Bu süreçte tütün ticaretiyle uğraşan bir tüccar sınıfı ortaya çıkmıştır. ${ }^{67}$

Tütün kullanımı ve ticaretinin artmasıyla, devletler bir taraftan bu ürünün üretim, pazarlama ve kullanımını kontrol etmeye çalışmışlar diğer taraftan da ürüne yüksek vergiler koymuşlardır. Buna rağmen

\footnotetext{
65 Yapucu, a.g.t., s.174.

${ }^{66}$ Oktay Gökdemir, Aydın Vilayetinde Tütün Rejisi, Basılmamış Doktora Tezi, Dokuz Eylül Üniversitesi Atatürk İlkeleri ve İnkılap Tarihi Enstitüsü, İzmir, 1994, s.2.

67 iç Anadolu'da ilk tütün üretiminin Ankara, Haymana ve Çankırı'da yapıldığı görülmektedir. Fehmi Yılmaz, Osmanlı Imparatorluğu'nda Tütün, Basılmamış Doktora Tezi, Marmara Üniversitesi, Türkiyat Araştırmaları Enstitüsü, İstanbul 2005, s.15-37.
}

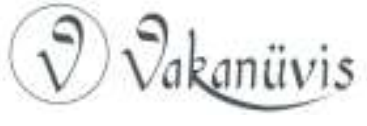


tütün kullanımı azalmadığı gibi tütün kaçakçılığı da mühim bir mesele olarak ortaya çıkmıştır. ${ }^{68}$ Tütün üretiminde ve ticaretinde ortaya çıkan kaçakçılığın temel nedeni büyük ölçüde tütüne getirilen yasaklamalardır. ${ }^{69}$ Kaçakçııı̆ın diğer bir nedeni ise $1883^{\prime}$ te kurulan ve tütün de tekel oluşturan reji yönetiminin tütün üreticileri üzerindeki baskısı ve düşük ücret politikalarıdır. ${ }^{70}$ Buna karşın tütün üreticisi çareyi kaçakçılık yapmakta bulmuştur. İncelenen dönemde hükümet, tütün kaçakçılığını önlemek için çeşitli önlemler almış ise de kaçakçılı̆ı̆ önüne tam olarak geçilememiştir.

Tütün kaçakçılığı yapanlar arasında serseriler, çeteler, üreticiler, tüccarlar, devlet memurları ve güvenlik güçleri yer almıştır. ${ }^{71}$ Hatta Ayaş kazasına bağlı Güdül nahiyesi ahalisinin tamamının bu işle meşgul olduğu belgelerden anlaşılmıştır. ${ }^{72}$ Görüldüğü üzere her meslek ve sınıftan geniş bir insan kitlesi tütün kaçakçılığıyla meşgul olmuştur. Öte yandan ekonomik sıkıntılar, reji baskısı ve güvenlik zafiyetleri kaçakçılık faaliyetlerini arttırmıştır. Ülkenin her yerinde olduğu gibi Ankara vilayetinde de tütün kaçakçılığının artması üzerine bazı tedbirler alınmıştır. ${ }^{73}$ Kaçakçıların yakalanması, reji kolcularıyla jandarmanın iş birliği yapması, komşu vilayetlerle birlikte hareket edilmesi, ağır para cezası verilmesi, kolcu sayısının arttırılması ve silahlandırılması bu

\footnotetext{
68 Halim Demiryürek, Ertuğrul Sancağı (1900-1918), Bilecik Şeyh Edebali Üniversitesi Yayınları, Bilecik, 2015, s.78.

69 Yılmaz, a.g.t., s.127-134.

70 Mehmet Akpınar, "Reji Uygulamalarına Bir Tepki: Tütün Kaçakçılığı”, Türkler, Cilt 14, Yeni Türkiye Yayınları, Ankara, 2002, s.305-313.

71 BOA, BEO. 3081/231027, 8 Cemazeyilevvel 1325/19 Haziran 1908; BOA, Y.MTV. 310/181, 8 Cemazeyilevvel 1326/8 Haziran 1908; BOA, DH. MKT. 2732/5, 15 Muharrem 1327/6 Şubat 1909; BOA, DH. ID. 94/19, 20 Rebiülahir 1329/20 Nisan 1911; BOA, DH. iD. 94/68, 25 Cemazeyilahir 1330/11 Haziran 1912; BOA, DH. iD. 94/16, 18 Zilkade 1330/29 Ekim 1912.

72 "Ayaş kazasına tabi Güdül nahiyesi ahalisinin heman umumiyetle öteden beri meslek ittihaz itdikleri tütün kaçakçılığı...". BOA, DH. ID. 94/19, 20 Rebiülahir 1329/20 Nisan 1911.

73 "Ankara Reji Nezâreti'nden alınan bir tariratta idare-i inhisariye ile hazine-i celile hazirine olarak oralarca tütün kaçakçıı̆ı̆ının fevkalade tevsi' itdiği...". Başbakanlık Osmanlı Arşivi (BOA), Dâhiliye Nezâreti Mektubî Kalemi (DH. MKT.), 2677/11, 13 Zilkade 1326/7 Aralık 1908.
}

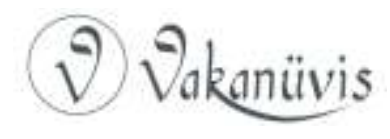


tedbirlerden bazılarıdır. ${ }^{74}$ Bunun yanı sıra kaçak tütünlerden alınan nakit para cezasından güvenlik güçlerine de pay verilmesi önerilmiş, ancak bu öneri kanuna aykırı bulunarak kabul edilmemiştir. ${ }^{75}$

Tütün kaçakçılarının takibi esnasında meydana gelen çatışmalar birçok can kaybı ve yaralanmalara sebep olmuştur. ${ }^{76}$ Çatışmalar genellikle kaçakçılar ile Reji kolcuları ve jandarmalar arasında yaşanmıştır. ${ }^{77}$ Ankara geçiş güzergâhında olduğu için güneyden ve kuzeyden gelen kaçak tütünler doğal olarak buradan taşınmıştır. Ankara valisi Ebubekir Bey, Dâhiliye Nezâreti'ne gönderdiği yazıda, kaçak tütünlerin Ankara'ya ait olmadığını, Düzce ve Hendek'ten getirildiğini belirtmiştir. Ebubekir Bey, kaçakçıların kalabalık ve silahlı olduklarını, buna karşın jandarmanın bunlarla mücadelede etkisiz kaldığını, bilhassa Kastamonu ve İzmit vilayetlerinin bu konuda gerekli tedbirleri almalarının şart olduğunu ifade etmiştir. ${ }^{78}$

74 BOA, BEO. 3081/231027, 8 Cemazeyilevvel 1325/19 Haziran 1908; BOA, Y. MTV. 310/181, 8 Cemazeyilevvel 1326/8 Haziran 1908; BOA, DH. ID. 94/19, 20 Rebiülahir 1329/20 Nisan 1911; Başbakanlık Osmanlı Arşivi (BOA), Dâhiliye Nezâreti Emniyet-i Umumiye Emniyet Şubesi (DH. EUM. EMN), 80/15, 19 Recep 1332/13 Haziran 1914; BOA, DH. EUM. EMN. 87/46, 24 Şaban 1332/18 Temmuz 1914.

75 BOA, DH. ID. 95/42, 11 Rebiülevvel 1330/29 Şubat 1912.

${ }^{76}$ BOA, DH. MKT. 1266/53, 3 Cemazeyilahir 1328/12 Haziran 1910; BOA, DH. EUM. EMN. 5/55, 14 Cemazeyilahir 1330/31 Mayıs 1912.

77 BOA, DH. ID. 94/68, 25 Cemazeyilahir 1330/11 Haziran 1912; BOA, DH. ID. 94/16, 18 Zilkade 1330/29 Ekim 1912.

78 "...vilayet dâhilinde sarf ve istihal idilen kaçak tütünler mahsulat-ı mahalliyeden olmayub kısmı küllisi Düzce kazasıyla Hendek nahiyesinden gelmekde ve kaçakçılığı sanat ittihaz iden Düzceli Arslan Beyle Kavak Mahmud ve Nuri ve Şahin ve kolcu başılıkdan muhric Âdem Beylerin tahtı riyasetinde müteşekkil ve cümlesi martini tüfenkleriyle müsellah elli altmış kadar eşhas-ı şerire tarafından mühtecem'en götürülmekde ve her biri de mevcudu pek az olan jandarmadan bunlara mukabeleye kafi kuvvet tedarikide müşkil olmakda bulunduğundan mahallerince malum olan bu mesellü meşhur kaçakçıların hükümeti mahalliyece kefalet-i kuvveye rabıtayla beraberine hal ve hareketleri mahallerince nazarı dikkatten tutulmayarak gerek bunların ve gerek sair eşhasın kaçak tütünle bu taraflara müteveccihen hareketlerinden buraca vaktiyle haberdar olarak bir müfreze-i mahsusa bi-tertib icab iden mevaki'e sevk olunmak üzere derhal telgrafla malumat itası hususunun Kastamonu vilayetiyle izmid mutasarrıflığına emrü ihtar buyurulmasının lüzumu arz ve izbarı ifade kılınmış ve şu suret-i kaçakçıı̆ı̆ın men'ine bir dereceye kadar hidmet ideceği tabi' bulunmuş olmakla ol vechle ibka-yı muktezası...". BOA, DH. MKT. 2732/5, 15 Muharrem 1327/6 Şubat 1909.

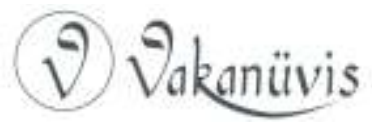


Güvenlik güçleri tütün kaçakçılarını yakalayarak ellerindeki tütüne ve silahlara el koymuşlar ise de, bir süre sonra bu kişiler yine silahlanarak kaçakçılığa devam etmişlerdir. Bunun sebebi kaçakçılığa yönelik ceza-i müeyyidelerin yetersiz kalması ve kaçakçıların kısa sürede serbest bırakılmasıdır. Birçoğu silahlı dolaşan tütün kaçakçıları, silahları büyük ölçüde silah kaçakçılarından temin etmişler, yeri geldiğinde kendileri de silah kaçakçılığına ortak olmuşlardır. Silah kaçakçıları da tütün kaçakçıları gibi kaçak silahları gizlice Karadeniz ve Akdeniz sahillerinden iç kesimlere doğru taşıyarak daha önce anlaştıkları aracılara ulaştırmışlardır. Ankara vilayeti silah kaçakçılığının yoğun olarak yaşandığı bir bölge olmamasına rağmen bu hususta belgelerde bazı örneklere rastlanmıştır. ${ }^{79}$

31 Aralık 1911 tarihli belgede Amerikan bandıralı Virjinya vapuru personelinden bir kişi, Kasap Mahmut ve Dükkâncı Kamil'e satışı yasak olan Martini ve Revolver markalı silahları satmak istemiştir. Ancak Mahmut ve Kâmil gemiye binip silahlar hakkında konuşurlarken o sırada orada bulunan polis memuru issmail'i fark edince silahları Ayaş kazasına götürmeye cesaret edememişlerdir. ${ }^{80}$ Bu kaçakçılık girişimi biraz da şans eseri önlenmiştir. Burada dikkati çeken husus Amerikan gemisinde silah kaçakçılığının yapılıyor olmasıdır.

Karadeniz üzerinden de zaman zaman Amerikan, İngiliz ve Rus silahlarının kaçak yollarla yurda sokulduğu ve Rumlar aracılığıyla iç bölgelerdeki eşkıyalara satıldığı anlaşılmaktadır. ${ }^{81}$ Ankara vilayetindeki kaçakçılığa dair vali Reşit Bey'in her ne kadar erken bir tarihe ait olsa da 1908'deki yazısı oldukça aydınlatıcıdır. Vali Reşit Bey, kaçakçıların bir kısmının Akdeniz havalisinden gelip Bursa, Konya, Kayseri ve Sivas'a, bir kısmının da Karadeniz sahilinden aldıkları silahlarla Kastamonu'yu geçip Yozgat ve Çorum'a ulaştıklarını belirtmiştir. Reşit Bey'e göre kaçakçılığın stratejik noktaları, Ereğli, Zonguldak, Ayvalık gibi yerlerdir. Reşit Bey, kaçakçılığın gerçek anlamda önlenebilmesi için öncelikle kıyı kesimlerinde ciddi önlemlerin alınması gerektiğini savunmuştur. Çünkü

\footnotetext{
79 BOA, DH. ID. 94/19, 20 Rebiülahir 1329/20 Nisan 1911.

80 BOA, DH. ID. 94/35, 10 Muharrem 1330/31 Aralık 1911.

${ }^{81}$ Başbakanlık Osmanlı Arşivi (BOA), Dâhiliye Nezâreti Emniyet-i Umumiye Müdiriyeti Altıncı Şube (DH. EUM. 6. Şb), 37/49, 12 Şaban 1336/23 Mayıs 1918.
}

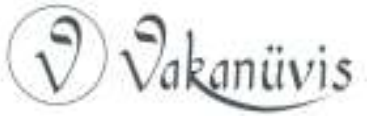


kaçak silahlar iskele ve limanlardan iç kesimlere dağıtılmaktadır. ${ }^{82}$ Vali Bey'e göre kaçakçıların çoğunluğu Erzurum ve Sivas çevresinden Kürt, Çerkez ve Ermeni gruplarından oluşmaktadır. Özellikle Ermenilerin bu konuda mahir olduklarını ve Müslümanları da bu yönde teşvik ettiklerini söyleyen Reşit Bey, tütün kaçakçılarının da ekseriyetle silah kaçakçılığı yaptıklarını ifade etmiştir. Vali Bey, kaçakçılığın önlenmesi için kaçakçılarla mücadele eden kolcuların görevlerini güvenlik güçlerine devretmelerini önermiştir. Ayrıca kaçakçılara verilen cezaların yetersiz olduğunu ve kanunda gerekli değişikliklerin yapılması gerektiğini vurgulamıştır. ${ }^{83}$ Vali Reşid Bey'in tespitlerinin oldukça gerçekçi olduğu söylenebilir. Keza kendisinden sonra da kaçakçılık sorunu benzer bir süreç izlemiştir.

\section{Ankara, Aydın ve Trabzon Vilayetlerinde Yaşanan Kaçakçılık Olaylarına Dair Bir Karşılaştırma}

Incelenen dönemde, Ankara, Orta Anadolu'nun, Aydın, Batı Anadolu'nun, Trabzon ise Kuzey Anadolu'nun merkezi konumunda bulunan vilayetlerdir. Dolayısıyla bu vilayetlerde yapılan kaçakçılı̆ın birbiriyle karşılaştırılması, Anadolu coğrafyasında yapılan kaçakçılık faaliyetlerinin niteliği, türü ve yetkililerin tutumuna dair bir değerlendirmeye imkân verecektir. ${ }^{84}$

Kaçakçılığın nedenleri bakımından bir karşılaştırma yapıldığında şunlar söylenebilir: Ankara vilayetinde yapılan kaçakçılı̆̆ın özellikle de tütün kaçakçılığının temel nedeni, çeşitli yasaklamalar, yüksek vergiler, Reji idaresinin baskısı ve ekonomik sıkıntılardır. Trabzon vilayetinde yapılan kaçakçılığın nedenleri arasında, vergi kaçırmak suretiyle kâr elde etmek, bazı ürünlere konulan yasaklamalar, köylü, esnaf ve tüccarın karşılaştığı ekonomik sıkıntılar yer almıştır. Karadeniz bölgesindeki kaçakçılık faaliyetlerinde dikkat çeken husus, tütün üretim ve ticaretinin artmasıyla beraber bu meta üzerinde meydana gelen yasadışı

82 Örneğin, yabancı bir vapur kumpanyasının İnebolu, Samsun, Giresun, Trabzon iskelelerine uğrayarak kaçak silahları Anadolu'ya sevk ve ihraç edeceği ihbarı üzerine güvenlik birimleri harekete geçerek vapuru alıkoymuşlardır. Yapılan tahkikat neticesinde vapurdaki kaçak silahlara el konulmuştur. Hamzaoğlu, a.g.t., s.96.

83 BOA, Y. MTV. 310/181, 8 Cemazeyilevvel 1326/8 Haziran 1908.

${ }^{84}$ Tütün kaçakçılığı her üç vilayetin de ortak sorunu olduğu için karşılaştırma ağırlıklı olarak bu olgu üzerinden yapılmıştır.

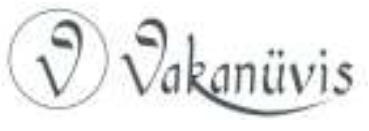


faaliyetlerdir. Tütünün Reji İdaresine geçişi bu faaliyetleri daha da arttırmıştır. ${ }^{85}$ Aydın vilayetinde yapılan kaçakçılığın nedenleri ise, Ege havzasının kaçakçılığa müsait olması, yerli ve yabancı tüccarın devletin vergi denetiminden kaçmak istemesi, gemilerin resmi gümrük hangarlarının haricinde gözden uzak bölgelerde yüklenip boşaltılmasıdır. Bunun yanı sıra ülkenin içinde bulunduğu ekonomik sıkıntılar da kaçakçılığa ortam hazırlamıştır. Düşük ücretle çalışan sivil ve asker memurların bir kısmı da mali sıkıntılardan kurtulmak için çeşitli suiistimallere ve kaçakçılığa bulaşmışlardır. ${ }^{86}$ Kaçakçılık faaliyetinin genellikle eşkıya çeteleri, üreticiler, tüccarlar, memurlar ve güvenlik güçleri gibi geniş bir kesim tarafından yapıldığını yukarıda söylenmişti. Dolayısıyla kaçakçıların niteliklerine bakıldığında, her üç vilayet için de ortak özellikler taşıdıkları söylenebilir.

Üç vilayeti, yapılan kaçakçılı̆ı̆n türleri açısından karşılaştırdığımızda, Ankara vilayetinde, tütün kaçakçılığının yanı sıra seyrek te olsa silah kaçakçılığı, Trabzon vilayetinde, tütün, tuz, maden ve silah kaçakçılı̆̆ı, ${ }^{87}$ Aydın vilayetinde ise, tütün, ecza-yı nariye denilen patlayıcı maddeler, silah, çam kabuğu ve kereste kaçakçılığının ${ }^{88}$ yapıldığını söylemek mümkündür.

Kaçakçılığı önlemek için her üç vilayette de bazı tedbirler alınmıştır. Ankara vilayetinde, kaçakçılığın önlenmesi için, reji kolcularıyla jandarmanın iş birliği yapması, komşu vilayetlerle birlikte hareket edilmesi, kaçakçılık suçuna ağır para cezası verilmesi, kolcu sayısının arttırılması ve silahlandırılması üzerinde durulurken, Trabzon vilayetinde, bölgenin kendine has özellikleri göz önüne alınarak bazı tedbirler alınmıştır. Karadeniz sahilinin belirli bölgelerine karakollar yapılması, sahilde donanımlı istimbotlar gezdirilmesi, gemi reislerinin kefalete bağlanması, bölgede yeterli sayıda kolluk kuvveti istihdam edilmesi, gerektiğinde Reji kolcularının silahlandırılması bunların belli başlılarıdır. ${ }^{89}$ Aydın vilayetinde ise kaçakçılığı önleme için alınan tedbirler, Trabzon vilayetinde alınan tedbirlerle benzerlik

\footnotetext{
85 Hamzaoğlu, a.g.t., s.4-5.

86 Yapucu, a.g.t. s.174-175.

${ }^{87}$ Bkz. Hamzaoğlu, a.g.t., s.35-63.

${ }^{88}$ Yapucu, a.g.t., s.175.

89 Hamzaoğlu, a.g.t, s.65-68.
}

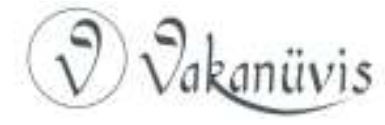


göstermektedir. Ancak silah kaçakçılığına karşı diğer vilayetlere nazaran daha sert tedbirler alınmıştır. ${ }^{90}$

Kaçakçıların faaliyetlerine gelince, bunlar, her türlü yasak emtianın alım ve satımını yapmışlardır. Ancak tütün, diğer emtialara nispetle en çok kaçakçılığı yapılan ürün olmuştur. Tütünün yanı sıra silah kaçakçılığı da zaman ve şartlara göre rağbet görmüştür. Kaçakçılar, Ankara ve çevresini daha çok bir geçiş güzergâhı olarak kullanmışlardır. Ancak kaçak tütünün bölgede pazarlanmasını da sağlamışlardır. Ayrıca silah kaçakçılığı yapanların da Ankara vilayetinin değişik bölgelerini kullandıkları da bir vakıadır. Kaçakçılar faaliyetlerini yürütürken, sık sık Reji kolcularıyla ve güvenlik güçleriyle karşı karşıya gelmişlerdir. Bu karşılaşmalar bazen yaralama ve ölümle sonuçlanan olaylara yol açmıştır. Ancak, bu tip olaylara Trabzon ve Aydın vilayetlerine nazaran Ankara vilayetinde daha az rastlanmıştır. Bunun temel nedeni kaçakçılı̆ı̆n bu vilayetlerde daha yoğun bir şekilde yapılıyor olmasıdır.

Osmanlı ülkesinin Anadolu coğrafyasını büyük ölçüde yansıtan bu üç vilayette yaşanan kaçakçılık faaliyetleri farklı açılardan değerlendirildiğinde, birbirine benzer yönleri olduğu gibi, bazı farklılıklara da tesadüf edilmektedir. Üç vilayetin, coğrafi, ekonomik ve sosyal açıdan birbirinden farklı olması, kaçakçılığın farklı tezahürlerini de beraberinde getirmiştir. Örneğin Karadeniz bölgesinde, tütün, tuz, silah, kereste kaçakçııı̆ı ön plana çıkarken, Ege bölgesinde, başta tütün ve silah olmak üzere çeşitli malların kaçak yollardan ticaretinin yapıldığı görülmüştür. Ankara merkezli Orta Anadolu'da ise tütün kaçakçılı̆̆ı ön plana çıkmıştır.

Karadeniz ve Ege'de kaçakçılığın yoğunlaştığı dönemlerde Ankara ve çevresi kaçak emtiayı diğer bölgelere geçirmek için kullanılmıştır. Karadeniz ve Ege'de kaçakçılıkla uğraşanların, Ankara vilayetinde kaçakçılık yapanlardan daha farklı kimliklere sahip oldukları söylenebilir. Karadeniz ve Ege'de Müslüman halkın yanı sıra Rum ve Ermeni vatandaşlar kaçakçılık faaliyetlerinde ön planda yer alırlarken, Ankara ve çevresinde ağırlıklı olarak Müslüman halk bu tür faaliyetlere karışmıştır. Kaçakçıların zaman zaman eşkıya çeteleriyle işbirliği yaptıkları ve yerel

90 Yapucu, a.g.t, s.178-179.

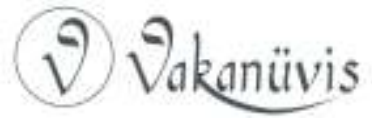


yönetimleri baskı altına aldıkları, hatta bazı durumlarda bu yöneticilerle işbirliği yaptıkları söylenebilir.

Kaçakçılığın arttığı dönemlerde, vergi gelirlerinin azalmasına paralel, kamu düzeni de sarsılmıştır. Bu gibi durumlarda, Karadeniz ve Batı Anadolu bölgeleri, Ankara ve çevresine nazaran daha olumsuz etkilenmiştir. Kaçakçılık faaliyetleri esnasında yaşanan çatışmalar birçok insanın yaralanmasına ve ölmesine yol açmıştır.

Merkezi hükümet ve yerel yönetim, kaçakçılığı önlemek için kanuni düzenlemelerin yanı sıra, kaçakçılık yapılan bölgelerin niteliğine göre pratik önlemler almıştır. Ancak, ekonomik ve sosyal sıkıntıların bir türlü giderilememesi, kaçakçııı̆ı önlemek için atılan adımları akim bırakmıştır.

\section{Sonuç}

Osmanlı'nın son döneminde ülkenin değişik bölgelerinde görülen ve sosyal, ekonomik, kültürel, ahlaki yozlaşmanın bir sonucu olan yolsuzluk (rüşvet, zimmetine para geçirme, suiistimal vs.) olaylarına Ankara vilayeti dâhilinde de rastlanmıştır. Vilayette en sık görülen yolsuzluk türünün zimmete para geçirme ve rüşvet vakaları olduğu anlaşılmıştır. Bu tür vakalara karışanların büyük çoğunluğunun kamu personeli oldukları tespit edilmiştir. Bunun yanı sıra yüksek rütbedeki bazı kamu görevlilerinin de yolsuzluğa bulaştıklarına şahit olunmuştur.

Ankara vilayetinde yolsuzlukların yanı sıra kaçakçılık olayları da kamu düzenini olumsuz etkilemiştir. Vilayette diğer kaçakçılık türlerinden ziyade ekseriyetle tütün kaçakçılığı yapılmıştır. Ancak yapılan kaçakçılığın büyük boyutlarda olduğu söylenemez. Tütün üretiminde ve ticaretinde ortaya çıkan kaçakçılığın temel nedeni tütüne getirilen yasaklamalar ve yüksek vergilerdir. Kaçakçııı̆ın bir diğer nedeni ise tütün de tekel oluşturan, reji yönetiminin tütün üreticileri üzerindeki baskısı ve düşük ücret politikasıdır. Incelenen dönemde merkezi hükümet, tütün kaçakçılığını önlemek için bir takım düzenlemeler yapmıştır. Yerel yöneticiler ellerindeki imkânlar çerçevesinde bunları yerine getirmeye çalışmışlardır. Merkezi hükümetin ve yerel yönetimin tütün kaçakçılığını önlemeye yönelik aldıkları tedbirler sorunu tam olarak çözememiş, kaçakçılık daha sonraki yıllarda da devam etmiştir. 
Osmanlı ülkesinin Anadolu coğrafyasını büyük ölçüde yansıtan Ankara, Aydın ve Trabzon vilayetlerinde (Orta Anadolu, Ege ve Karadeniz) yaşanan kaçakçılık faaliyetleri farklı açılardan karşılaştırıldığında, birbirine benzer yönlerin olduğu gibi, bazı farklılıkların da olduğu anlaşılmıştır. Örneğin Karadeniz bölgesinde, tütün, tuz, silah, kereste kaçakçılığı ön plana çıkarken, Ege bölgesinde, başta tütün ve silah olmak üzere çeşitli malların kaçak yollardan ticaretinin yapıldığı görülmüştür. Ankara merkezli Orta Anadolu'da ise tütün kaçakçılığı ön plana çıkmıştır.

Savaş gibi olağanüstü dönemlerde, Karadeniz ve Ege'de silah kaçakçıı̆ı̆ yoğunlaşırken, Ankara ve çevresi kaçak emtiayı diğer bölgelere geçirmek için kullanılmıştır. Karadeniz ve Ege'de Müslüman halkın yanı sıra Rum ve Ermeni vatandaşlar kaçakçılık faaliyetlerinde ön planda yer alırlarken, Ankara ve çevresinde ağırlıklı olarak Müslüman halk bu tür faaliyetlere karışmıştır. Kaçakçılar, eşkıya çeteleriyle işbirliği yapmanın yanı sıra, yerel yöneticileri baskı altına almışlar, bazı durumlarda da bu yöneticilerle işbirliği yapmışlardır.

Kaçakçılık, bir yandan ülke ekonomisine zarar verirken, diğer yandan da asayişi bozmuştur. Kaçakçılık faaliyetleri esnasında yaşanan çatışmalarda birçok insan yaralanmış veya ölmüştür. Merkezi hükümet ve yerel yönetim, kaçakçılığı önlemek için kanuni düzenlemelerin yanı sıra, kaçakçılık yapılan bölgelerin niteliğine göre pratik önlemler almıştır. Ancak, bu önlemler kısmen başarılı olmuştur.

\title{
Kaynakça
}

\author{
Arşiv Belgeleri \\ Başbakanlık Osmanlı Arşivi \\ BOA, DH. ID. 181/1. \\ BOA, DH. ID. 212/1. \\ BOA, DH. ID. 218/53. \\ BOA, DH. ID. $218 / 30$. \\ BOA, DH. ID. 94/19. \\ BOA, DH. ID. 94/68. \\ BOA, DH. ID. 94/16.
}

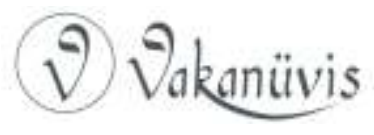


BOA, DH. ID. 95/42.

BOA, DH. ID. 94/19.

BOA, DH. ID. 94/19.

BOA, DH. ID. 94/68.

BOA, DH. ID. 94/16.

BOA, DH. ID. 94/19.

BOA, DH. ID. 94/35.

BOA, DH. MTV. 19/12.

BOA, DH. MTV. 21/77.

BOA, DH. MTV. 21/85.

BOA, DH. MTV. 21/12.

BOA, DH. MTV. 21/70.

BOA, DH. MTV. 36/13.

BOA, DH. MTV. 36/42.

BOA, DH. MTV. 49/15.

BOA, DH. MTV. 20/18.

BOA, DH. MTV. 21/73.

BOA, DH. MTV. 49/30.

BOA, DH. MTV. 62/7.

BOA, DH. MTV. 18/90.

BOA, DH. MKT. 2732/5.

BOA, DH. MKT. 1266/53.

BOA, DH. MKT. 2677/11.

BOA, DH. MKT. 2732/5.

BOA, DH. EUM. EMN. 80/15.

BOA, DH. EUM. EMN. 87/46.

BOA, DH. EUM. EMN. 5/55.

BOA, BEO, 4200/314996.

BOA, BEO. 3081/231027.

BOA, BEO. 3081/231027.

BOA, Y. MTV. 310/181.

BOA, Y. MTV. 310/181.

BOA, DH. MUI. 23/70.

BOA, DH. I.UM. 45/1.

BOA, DH. I. UM. 83/1.

BOA, DH. ŞFR. 56/297.

BOA, DH. ŞFR. 79/159.

BOA. DH. EUM. 6. Şb. 37/49.

\section{Resmi Yayınlar}

Takvim-i Vekayi, 1333 (1917). 
Ankara Vilayet Salnamesi, 1288 (1872).

Ankara Vilayet Salnamesi, 1318 (1900).

Ankara Vilayet Salnamesi, 1325 (1907).

Devlet Salnamesi, 60. Sene, 1328 (1912).

Düstur, II. Tertib, Cilt II.

Düstur, II. Tertib, Cilt III.

\section{Meclis-i Mebusan Zabıt Cerideleri}

MMZC, Cilt 1, İçtima 87, 1909.

MMZC, Cilt 2, İçtima 100, 1910.

MMZC, Cilt 2, içtima 73, 1911.

\section{Gazeteler}

Tanin, Sayı 361, 21 Ağustos 1325/3 Eylül 1909.

Tanin, Sayı 441, 11 Teşrinisani 1325/24 Kasım 1909.

\section{Araştırma Eserleri}

Ahmet Şerif, ANADOLU'DA TANIN, Cilt I, Mehmet Çetin Börekçi (Haz.), Türk Tarih Kurumu Yayınları, Ankara 1999.Akpınar, Mehmet, "Reji Uygulamalarına Bir Tepki: Tütün Kaçakçılığı", Türkler, Cilt 14, Yeni Türkiye Yayınları, Ankara, 2002, 305-313.

AKTÜRE, Sevgi, "1830'dan 1930'a Ankara'da Günlük Yaşam", Tarih İçinde Ankara II, Yıldırım Yavuz (der.), ODTÜ Mimarlık Fakültesi, Ankara 2001, 35-67.

Ali Haydar Mithat, Hatıralarım 1872-1946, Akçit Yayın, İstanbul 1946.

BALLI, Ergül, “ittihat ve Terakki'nin Tarım ve Toprak Politikası: Aydın Vilayeti Örneği", İttihatçılar ve İttihatçılık Sempozyumu Bildiriler Cilt III, 25 Kasım 2014, Türk Tarih Kurumu Yayınları, Ankara 2015, s.129-162.

BARKAN, Ömer Lütfi, "Tarihi Demografi Araştırmaları ve Osmanlı Tarihi", Türkiyat Mecmuası, Cilt 10, 1955, 1-26.

BAYUR, Hikmet Bayur, Türk Inkılabı Tarihi Cilt 1, Kısım 2, Türk Tarih Kurumu Yayınları, Ankara 1991.

BiRinCi, Ali, Refik Halit Karay: Ankara, İnkılap Kitabevi, i̇stanbul 2009.

ÇADIRCI, Musa, "1830 Genel Sayımına Göre Ankara Şehir Merkezi Nüfusu Üzerine Bir Araştırma", Osmanlı Araştırmaları, Sayı 1, 1980, 109-132.

DEMiRYÜREK, Halim, Ertuğrul Sancağı (1900-1918), Bilecik Şeyh Edebali Üniversitesi Yayınları, Bilecik, 2015.

ESiN, Taylan, Zeliha Etöz, 1916 Ankara Yangını: Felaketin Mantığı, İletişim Yayınları, ìstanbul 2015.

FAROQHi, Suraiya, Osmanlı'da Kent ve Kentliler, 5. Basım, Neyir Berktay (çev.), Tarih Vakfı Yurt Yayınları, İstanbul 2011.

FiNDLEY, Carter V., Osmanlı Imparatorluğu'nda Reform: Babıâli, 1789-1922, Tarih Vakfı Yurt Yayınları, İstanbul 2014.

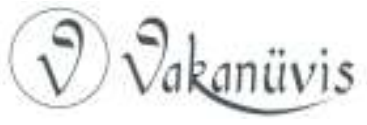


GÖKDEMiR, Oktay, Aydın Vilayetinde Tütün Rejisi, Basılmamış Doktora Tezi, Dokuz Eylül Üniversitesi Atatürk İlkeleri ve İnkılap Tarihi Enstitüsü, İzmir 1994.

GÜLER, Yusuf, Ankara Vilayetinde Idari Yapının Yöredeki Sosyo-Ekonomik Yapıya Olan Etkileri (1880-1919), Basılmamış Doktora Tezi, 19 Mayıs Üniversitesi Sosyal Bilimler Enstitüsü Tarih Ana Bilim Dalı, Samsun 2007.

GÜRAN, Tevfik, Osmanlı Devleti'nin Ilk istatistik Yıllığı 1897 Tarihi İstatistiksel Dizisi, Cilt 5, Ankara: Başbakanlık Devlet İstatistik Enstitüsü, 1997.

HAMZAOĞLU, Kubilay, Trabzon Vilayeti'nde Kaçakçılık (1855-1908), Yayımlanmamış Yüksek Lisans Tezi, Ondokuz Mayıs Üniversitesi Sosyal Bilimler Enstitüsü Tarih Anabilim Dalı, Samsun 2019.

KANSU, Aykut, 1909 Devrimi, İletişim Yayınları, İstanbul 1995.

KARACA, Taha Niyazi, Ermeni Sorununun Gelişim Sürecinde Yozgat'ta Türk Ermeni Ilişkileri, Türk Tarih Kurumu Yayınları, Ankara 2005.

KARAL, Enver Ziya, Osmanlı Imparatorluğunda IIlk Nüfus Sayımı 1831, II. Baskı, Başbakanlık Devlet İstatistik Enstitüsü, Ankara 1997.

KARAY, Refik Halit, Deli, Semih Lütfi Kitabevi, İstanbul 1939.

KARPAT, Kemal H., Osmanlı Nüfusu (1830-1914), Timaş Yayınları, İstanbul 2010.

KIRLI, Cengiz, Yolsuzluğun Icadı, Verita Yayınları, İstanbul, 2015.

KOÇ, Vehbi, Hayat Hikâyem, Apa Ofset, İstanbul 1974.

KOÇ, Yunus, "Yozgat", DiA, Cilt: 43, Ankara 2013, 559-564.

MMZC, Devre 1, Cilt 2, İctima 2, 7 Kanunuevvel 1325/20 Aralık 1909.

MUMCU, Ahmet, Osmanlı Devleti'nde Rüşvet (Özellikle Adli Rüşvet), Ankara Üniversitesi Hukuk Fakültesi Yayınları No. 252, Ankara, 1969.

ÖZDEMiR, Rıfat, XIX. Yüzyılın İlk Yarısında Ankara, Kültür ve Turizm Bakanlığı Yayınları, Ankara 1986.

ÖZSEMERCi, Kemal, Türk Kamu Yönetiminde Yolsuzluklar, Nedenleri, Zararları ve Çözüm Önerileri, Sayıştay Başkanlı̆̆ı, Ankara, 2003.

PAMUK, Şevket, Türkiye'nin 200 Yıllık Iktisadi Tarihi, 8. Basım, Türkiye İş Bankası Kültür Yayınları, İstanbul 2017.

Seyitdanlıŏlu, Mehmet, "Yerel Yönetim Metinleri: 1871 Vilayet Nizamnamesi ve Getirdikleri" Çağdaş Yerel Yönetimler, Cilt 5, Sayı 25, 1996, s.89-99.

Söylemez, M. Mahfuz, “Vilayet Salnâmelerine Göre Osmanlı'nın Son Döneminde Çorum", Hitit Üniversitesi Ilahiyat Fakültesi Dergisi, Cilt 6, Sayı 12, 2007/2, 33-35.

Şahin, İlhan, "Çorum", DiA, Cilt 8, İstanbul 1993. 373-376.

Şahin, İlhan, "Kırşehir", DiA, Cilt 25, İstanbul 2002. 481-485.

TEPAV, Yolsuzlukla Mücadele, 2. Basım, Matsa Basımevi, Ankara, 2006.

TEXIER, Charles, Küçük Asya, Cilt II, Çev. Ali Suat, Enformasyon ve Dokümantasyon Hizmetleri, Ankara 2002.

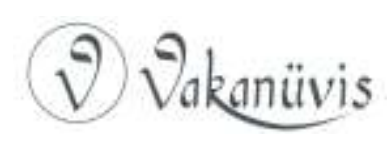


TOPRAK, Zafer, Ittihat-Terakki ve Cihan Harbi, 2. Basım, Kaynak Yayınları, istanbul 2016.

TUNÇER, Mehmet, Ankara (Angora Şehri Merkez Gelişimi (14-20. Yüzyıl), Ankara: Kültür Bakanlığı Yayınları, Ankara 2001.

Tural, Erkan, “II. Meşrutiyet Dönemi'nde Adliye ve Mezahip Nezareti'nde Bürokratik Reform", AÜHFD, C 57, Sayı 2, Yıl 2008, s.223-252.

TÜRK HUKUK LUGATI, 3. Basım, Başbakanlık Basımevi, Ankara, 1991.

YAPUCU, Olcay Pullukçuoğlu, Aydın Sancağı 1845-1914 (Sosyal, Ekonomik, Idari, Kültürel Durum), Yayımlanmamıs Doktora Tezi, Ege Üniversitesi Sosyal Bilimler Enstitüsü, Tarih Anabilim Dalı, İzmir 2006.

YILMAZ, Fehmi, Osmanlı Imparatorluğu'nda Tütün, Basılmamış Doktora Tezi, Marmara Üniversitesi, Türkiyat Araştırmaları Enstitüsü, İstanbul, 2005. 